Eur J Clin Chem Clin Biochem

1995; 33:563-568

(c) 1995 Walter de Gruyter \& Co.

Berlin · New York

\title{
Estimation of the Epidermal Growth Factor Receptor by the Hydroxyapatite Method in Human Breast Cancer $^{1}$ )
}

\author{
By Orland Diez-Gibert ${ }^{1}$, Maria E. Fernández-Montoli ${ }^{1,2}$, Victor Nàcher ${ }^{2}$ and Miguel A. Navarro \\ 1 Secció d'Hormones \\ 2 Unitat de Recerca Experimental \\ Ciutat Sanitària i Universitària de Bellvitge, Barcelona, Spain
}

(Received February 27/June 6, 1995)

Summary: Results of epidermal growth factor (EGF) receptor in human breast tumours show large variations, mainly due to the lack of standardization of the assays. Our EGF receptor values are higher than those reported previously which may be due to the use of the hydroxyapatite to separate bound and non-bound ligand in a radioligand assay. We found EGF receptors in 58\% (103/178) of the tumours (EGF receptor levels: 3 to 625 $\mathrm{fmol} / \mathrm{mg}$ of membrane protein, $\bar{x}=33.3$, median $=17.4$ ), with a median $K_{\mathrm{d}}$ of $0.642 \mathrm{nmol} / \mathrm{l}$. There was an inverse correlation between EGF receptors and estrogen receptors $(r=-0.215, p=0.00002$, Kendall correlation). There was a difference between EGF receptor content in grade II $(\bar{x}=16.9)$ and grade III tumours $(\bar{x}=59.3)(p=0.027)$, but not between histopathological types and lymph node status.

The relevance of EGF receptor largely depends on the reliability of its determination. The standardized EORTC methodology is a reproducible alternative which will expand EGF receptor determination and permit comparability of data between laboratories.

\section{Introduction}

Epidermal growth factor (EGF) is a 53 amino acid polypeptide $\left(M_{\mathrm{r}}=6000\right)$ isolated from the mouse submaxillary gland (1). The physiological role of EGF, although not yet completely understood, seems to be to regulate both the proliferation and/or differentiation in vitro and in vivo of a wide variety of cell types (2). Particularly, it is known to stimulate proliferation of human breast cancer cells in culture $(3,4)$. The biological effects (paracrine or autocrine) of EGF are mediated through high affinity binding to the specific cell-membrane receptor (EGF receptor) (2). This receptor is a $M_{\mathrm{r}}$ $=170000$ membrane glycoprotein characterized by tyrosine kinase activity, and its intracellular domain is homologous to sequences of the oncogen c-erbB- $2(5,6)$,

\footnotetext{
1) Work supported by the FIS grant $90 / 481$ and the Fundacio August Pi i Sunyer
}

and also serves as specific receptor for transforming growth factor- $\alpha$ (TGF $\alpha)$ (7).

The presence of EGF receptor in human breast tumours has been reported by many groups (8). The majority of these studies has shown that the presence of EGF receptor is inversely correlated with steroid receptor content and provides valuable, although controversial, prognostic information in breast cancer $(9$, 10). There is still no consensus on EGF receptors role in prognosis, but recent studies have supported the hypothesis that EGF receptor may be useful for predicting response to endocrine therapy (11) or as a target for new types of treatment (12). The most widely used method of receptor quantitation has been radioligand assay in which ${ }^{125}$ I-labelled EGF is incubated with tumoural membranes. High affinity binding specific for EGF has been reported in $16 \%$ to $91 \%$ 
of primary breast tumours at levels ranging from 1 to $3600 \mathrm{fmol} / \mathrm{mg}$ of protein, with"a median of the distribution ranging from 1.1 to $40 \mathrm{fmol} / \mathrm{mg}$ of protein in the various studies reviewed (8). These large variations can be explained by the absence of standardization of tissue-processing and assay conditions (13), and the heterogeneity of clinical material tested as well.

Our study focuses on the estimation of EGF receptor using standard methods for iodination of the ligand (14), separation of bound and free ligand and a binding assay standardized in accordance with the recommendations of the EORTC Receptor Study Group (15), and we compared our results with those obtained by other researchers with the same methodology. We also studied the association between EGF receptor and steroid receptors, and histopathological characteristics of the tumours.

\section{Materials and Methods \\ Patients and tumour samples}

Surgical samples' were obtained from 178 patients with primary breast tumours. Thirty-five percent were premenopausal (mean age $=42.5$ years, range $=26-50$ ) and $65 \%$ postmenopausal (mean age $=63.9$ years, range $=51-92$ )

The histopathological tumour type was known in 153 cases. The post-operative tumour size (pT) was available in 160 cases, the axillary lymph-node status (pN) in 157 cases, and the ScarffBloom-Richardson histopathological differentiation grade in 132 cases. Patient and tumour characteristics are shown in table 1.

\section{Preparation of tissues}

Samples were obtained at surgery, dissected from fat and necrotic parts and stored at $-80^{\circ} \mathrm{C}$ until processed. When assayed, the sam-

Tab. 1 Patient and tumour characteristics. Numbers in parenthesis: percentage.

\begin{tabular}{lrr}
\hline Patients & 178 & \\
- pre-menopausal & 63 & $(35)$ \\
- post-menopausal & 115 & $(65)$ \\
& & \\
Tumour size & 160 & \\
- pT1 < $2 \mathrm{~cm}$ & 51 & $(32)$ \\
- pT2 2- 5 cm & 76 & $(47)$ \\
- pT3 5-10 cm & 6 & $(4)$ \\
- pT4 & 27 & $(17)$ \\
& & \\
Nodal status & 157 & \\
- Node-negative & 86 & $(55)$ \\
- Node-positive & 71 & $(45)$ \\
& & \\
Tumour histopathology & 153 & \\
- intraductal & 5 & $(3)$ \\
- ductal & 136 & $(89)$ \\
- lobular & 9 & $(6)$ \\
- others & 3 & $(2)$ \\
Differentiation grade & & \\
- G I & 132 & \\
- G II & 15 & $(11)$ \\
- G III & 56 & $(42)$ \\
\hline
\end{tabular}

ple was homogenized with a Polytron apparatus $(3 \times 10 \mathrm{~s}$ bursts) in an ice-cold buffer $(10 \mathrm{mmol} / \mathrm{l}$ Tris- $\mathrm{HCl}, 0.5 \mathrm{mmol} / 1$ dithiothreitol, $1.5 \mathrm{mmol} / \mathrm{l}$ EDTA, $1 \mathrm{mmol} / \mathrm{l}$ monothioglycerol; $\mathrm{pH} 7.4)(1+5$, $w / v)$. The homogenate was centrifuged for $1 \mathrm{~h}$ at $105000 \mathrm{~g}$. The supernatant was used for the assay of estrogen receptors and progesterone receptors and the membrane pellet was stored at $-80^{\circ} \mathrm{C}$, up to four weeks, for EGF receptor determination.

\section{Estrogen receptor and progesteroné receptor assays}

Estrogen receptor (ER) and progesterone receptor (PgR) content were measured with two enzyme-immunoassays (ER-EIA and PgR-EIA Monoclonal kits, Abbott Laboratories). The assays were performed following the manufacturer's instructions. Tumours with a steroid receptor content lower than $10 \mathrm{fmol} / \mathrm{mg}$ protein were considered negative in each case.

\section{EGF receptor assay}

The stored pellets were resuspended in $2-2.5 \mathrm{ml}$ of assay buffer (10 mmol/ $\mathrm{K}_{2} \mathrm{HPO}_{4} / \mathrm{KH}_{2} \mathrm{PO}_{4}, 1,5 \mathrm{mmol} / 1 \mathrm{~K}_{2} \mathrm{EDTA}, 3 \mathrm{mmol} / \mathrm{l}$ $\mathrm{NaN}_{3}, 10 \mathrm{mmol} / \mathrm{l}$ monothioglycerol, glycerol (volume fraction 0.1 ), $50 \mu \mathrm{mol} / 1$ bacitracin; $\mathrm{pH}$ 7.4) by means of Polytron homogenizer ( $10 \mathrm{~s}$ burst) on ice. The homogenate was centrifuged $10 \mathrm{~min}$ at 800 $g$ to obtain cellular membranes in the supernatant. A $100 \mu$ l aliquot was taken for membrane protein determination. To the remaining cell membrane sample assay buffer containing bovine serum albumin was added (final concentration $1 \mathrm{~g} / \mathrm{l}$ ).

EGF receptor was determined by a multiple point ligand binding assay. Aliquots of cell membrane preparation were incubated with ${ }^{125}$ I-labelled mouse-EGF tracer (specific activity $=1110 \times 10^{10}$ $\mathrm{Bq} / \mathrm{mmol}$ ) at final concentrations ranging from 2.5 to $0.07 \mathrm{nmol} / \mathrm{l}$ for 16 hours at $20^{\circ} \mathrm{C}$. The mouse EGF (Sigma) was iodinated with the lactoperoxidase - glucose oxidase reagent (Enzymobead, BioRad). Non-specific binding was assessed by incubation with 250 fold excess of unlabeled mouse EGF ( $225 \mathrm{nmol} / \mathrm{l})$. Receptor-bound and free ligand were separated using hydroxyapatite (DNA grade Biogel HTP, Bio-Rad). Hydroxyapatite suspension was added (final volume: $240 \mu \mathrm{l}$ ), and the assay tubes were incubated for 1 hour at room temperature. Subsequently, tubes were centrifuged for $2 \mathrm{~min}$ at $800 \mathrm{~g}$ and washed twice with phosphate buffer. The supernatant containing the unbound ligand was decanted and the hydroxyapatite pellet was assessed in a gamma-ray counter. EGF receptor values were calculated with Scatchard analysis (16), performed using a nonlinear weighted regression. EGF receptor values were expressed as $\mathrm{fmol} / \mathrm{mg}$ of protein. The cut-off point was $3 \mathrm{fmol} / \mathrm{mg}$ of membrane protein, which was the lowest concentration that could be measured reliably (correlation coefficient from the Scatchard plot higher than 0.7).

\section{Protein analysis}

Protein concentration was determined by the method of Lowry et al. (17). The concentration of the membrane preparation was adjusted to the range from 0.5 to $2 \mathrm{~g} / \mathrm{l}$.

\section{Statistical analysis}

We used non-parametric tests, since the receptor data were not normally distributed: Mann-Whitney's U test, $\chi^{2}$ analysis for categorical variables, Spearman rank correlation and Kendall rank correlation for continuous variables and multiple regression for multivariate analysis.

\section{Results}

\section{EGF receptor}

Fifty-eight percent (103/178) of the tumours analyzed contained specific, saturable, high affinity binding sites 
for EGF. Total EGF receptor content ranged from 3 to $625.1 \mathrm{fmol} / \mathrm{mg}$ of membrane protein, with a mean value of $22.2 \mathrm{fmol} / \mathrm{mg}$ (median value of $17.4 \mathrm{fmol} / \mathrm{mg}$ ). Scatchard curves showed only one type of association site, with a median $K_{d}$ of $0.462 \mathrm{nmol} / \mathrm{l}$. Value distribution of EGF receptor in the population studied is shown in figure 1 . The histogram shows a log-normal distribution.

Analysis of the steroid receptor results revealed that $70 \%(125 / 178)$ of the tumour biopsy samples were estrogen receptor-positive and 50\% (89/178) were progesterone receptor-positive. According to estrogen/progesterone receptor phenotypes, $49 \%$ of tumours were estrogen/progesterone receptor-positive, $21 \%$ were estrogen receptor-positive/progesterone receptor-negative, $1 \%$ was estrogen receptor-negative/progesterone receptor-positive and $29 \%$ estrogen/progesterone receptor-negative.

EGF receptor was found to be positive in $48 \%(60 / 125)$ of estrogen receptor-positive and in $81 \%(43 / 53)$ of estrogen receptor-negative breast tumour biopsy samples, showing a significant inverse correlation $\left(\chi^{2}=16.8, \mathrm{n}=178, p=0.00001\right)$, and also in $48 \%$ $(43 / 90)$ of progesterone receptor-positive and in $68 \%$ $(60 / 80)$ of progesterone receptor-negative breast tumour biopsy samples, also with an inverse correlation $\left(\chi^{2}=7.6, \mathrm{n}=178, p=0.006\right)$. Table 2 shows the percentages of EGF receptor-positive tumours and EGF receptor content of tumours distributed according to the combined steroid receptor status.

EGF receptor content in estrogen receptor-positive tumours $(\bar{x}=18.9$, median $=14.8 \mathrm{fmol} / \mathrm{mg})$ was significantly lower than that in estrogen receptor-negative tumours $(\bar{x}=53.4$, median $=18.5 \mathrm{fmol} / \mathrm{mg}, p=0.026)$. Tumours with high concentrations of EGF receptor ( $>100 \mathrm{fmol} / \mathrm{mg}$ ) were all steroid receptor-negative. The

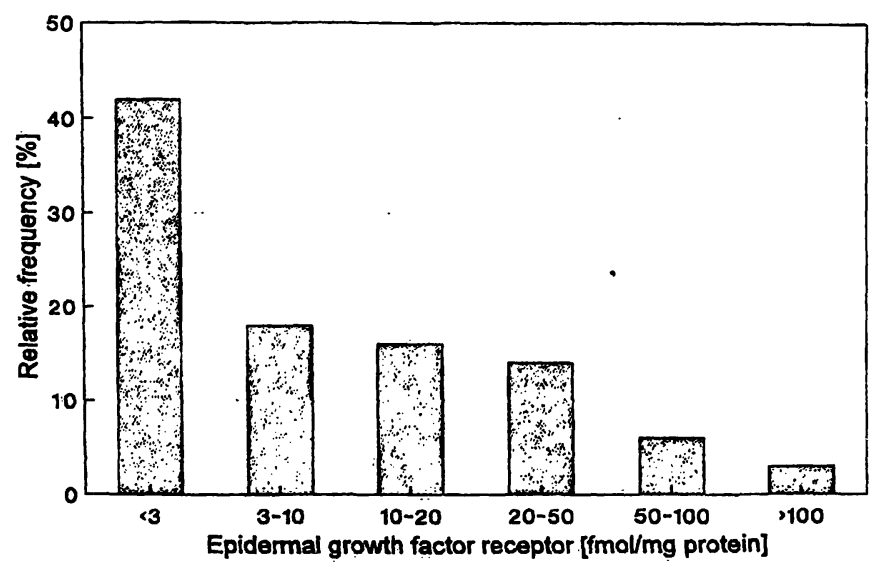

Fig. 1 Distribution of EGF receptor values in the study population. The distribution ranges from 3 to $625.1 \mathrm{fmol} / \mathrm{mg}$ membrane protein $($ median $=17.4)$. content of EGF receptor decreased with increasing steroid receptor values (tab. 3 ).

We found a negative correlation between EGF receptor and estrogen receptor content $(r=-0.215$, $p=0.00002)$ and between EGF receptor and progesterone receptor content $(r=-0.128, p=0.011$; Kendall rank correlation).

Multivariate analysis with EGF receptor as dependent variable and steroid receptors as independent variables showed that only estrogen receptor was independently associated with EGF receptor (estrogen receptor: $p=0.008$, progesterone receptor: $p=0.56$ ). This indicates that the association between EGF receptor and progesterone receptor depends on the strong association between progesterone receptor and estrogen receptor $(r=0.4, p<0.000001)$ (Spearman rank correlation).

In the comparison between pre- and postmenopausal women we found differences in EGF receptor content (pre: $\bar{x}=55.6 \mathrm{fmol} / \mathrm{mg}$ ), median $=24.2$; post: $\bar{x}=19.34 \mathrm{fmol} / \mathrm{mg}$, median $=13.8 ; p=0.002$ ). These results show an inverse relation with the values of estrogen receptor, which are higher in the postmenopausal group. No correlation was observed between EGF receptor status and age.

\section{Histological grade}

According to the Scarff-Bloom grading, 53\% (8/15) of grade I tumours, $55 \%$ (31/67) of grade II and 64\% (39/ 61) of grade III were EGF receptor-positive. No correlation was observed between EGF receptor and tumour grade, but considering only the tumours with high EGF receptor content $(>50 \mathrm{fmol} / \mathrm{mg}), 73 \%(8 / 11)$ were of grade III, showing a decrease of EGF receptor expression with tumour differentiation. There was a statistically significant difference between EGF receptor content in grade II tumours $(\bar{x}=16.9 \mathrm{fmol} / \mathrm{mg})$, median $=9.7)$ and grade III tumours $(\bar{x}=59.3$, median $=17.6)$ $(p=0.027)$.

\section{Axillary nodes and histological subtypes}

Regardless of the number of axillary lymph nodes invaded, there was no correlation with EGF receptor content or distribution. There was no difference between invasive, non-invasive ductal and lobular disease in the proportion of EGF receptor-positive tumours. No statistical difference was observed in terms of distribution.

\section{Discussion}

The percentage of EGF receptor-positivity in human breast cancer, measured by radioligand binding asssay, 
Tab. 2 Mean EGF receptor content of EGF receptor-positive tumours distributed according to the combined steroid receptor status.

\begin{tabular}{|c|c|c|c|}
\hline & \multicolumn{2}{|c|}{ EGF receptor-positive tumours } & \multirow{2}{*}{$\begin{array}{l}\text { EGF receptor content } \\
\text { (fmol/mg) }\end{array}$} \\
\hline & $\%$ & $\mathrm{n}$ & \\
\hline $\begin{array}{l}\text { Estrogen receptor-positive/Progesterone receptor-positive } \\
\text { Estrogen receptor-positive/Progesterone receptor-negative } \\
\text { Estrogen receptor-negative/Progesterone receptor-positive } \\
\text { Estrogen receptor-negative/Progesterone receptor-negative }\end{array}$ & $\begin{array}{l}47 \\
50 \\
50 \\
82\end{array}$ & $\begin{array}{l}(41 / 87) \\
(19 / 38) \\
(1 / 2) \\
(42 / 51)\end{array}$ & $\begin{array}{l}21.1^{*, * * *} \\
14.4^{*, * *} \\
17.2 \\
54.2^{* *, * * *}\end{array}$ \\
\hline total & 58 & $(103 / 178)$ & \\
\hline
\end{tabular}

${ }^{*} p<0.04 ;{ }^{* *} p<0.01 ; * * * p<0.018$

Tab. 3 Decrease of mean EGF receptor values ( $\mathrm{fmol} / \mathrm{mg}$ of membrane protein) with increase of estrogen receptor and progesterone receptor content (fmol/mg cytosolic protein) in breast tumours.

\begin{tabular}{cll}
\hline $\begin{array}{l}\text { Steroid } \\
\text { receptor } \\
\text { (fmol/mg) }\end{array}$ & $\begin{array}{l}\text { Estrogen } \\
\text { receptor } \\
\text { (fmol/mg) }\end{array}$ & $\begin{array}{l}\text { Progesterone } \\
\text { receptor } \\
\text { (fmol/mg) }\end{array}$ \\
\hline$<10$ & 53.4 & 42.4 \\
$10-50$ & 22.1 & 24.4 \\
$50-100$ & 25.4 & 25.0 \\
$100-250$ & 10.9 & 15.5 \\
$250-500$ & 14.0 & 13.6 \\
$>500$ & 5.6 & 7.1 \\
\hline
\end{tabular}

varied from $16 \%$ to $91 \%(8)$. The differences in tissue preparation and assay methodology are the most likely explanations for these variations. We found EGF receptor to be present in $58 \%$ of human breast cancers. Our positivity rate is very close to that obtained by authors who used the same methodology (18) and higher than that of many other authors (8).

Quantitative results of EGF receptor in our study $(\bar{x}=33.3 \mathrm{fmol} / \mathrm{mg}$, median $=17.4 \mathrm{fmol} / \mathrm{mg})$ also exceed most of the values reported by other authors using radioligand binding assay which may be attributable to certain aspects of tissue preparation, the use of $800 \mathrm{~g}$ supernatant compared to higher $g$-values in most reported studies (19-21), and the EORTC methodology that we followed, such as the use of hydroxypatite to separate bound and non-bound ligand. Regarding the affinity of the receptor for its ligand, we found a $K_{\mathrm{d}}$ similar to that described in the literature for breast cancer. In this sense, we think that discrepancies regarding the presence of a single or two classes of binding sites may be due to methodological differences.

There is general agreement that the proportion of EGF receptor-positive tumours is significantly higher in estrogen receptor-negative than in estrogen receptorpositive tumours. In our study we found $81 \%$ of estrogen receptor negative tumours to be EGF receptor-positive. This concurs with in vitro studies of estrogen recep- tor-negative human breast cancer cell lines, which show a constitutive expression of EGF receptor (22). The percentages of EGF receptor-positivity in each subgroup of tumours, separated according to the steroid receptor status, are similar to those obtained previously $(13,18)$ by the same EGF receptor method, which is of interest with regard to the reproducibility of the assay. Furthermore, the use of different methods in the measure of steroid receptors (dextran-coated charcoal in all previous works and enzymoimmunoanalysis in our case) does not seem to influence the results (phenotypical percentages) obtained for both types of receptors, nor does it alter the conclusions.

We showed that EGF receptor-positivity and EGF receptor content were inversely associated with steroid receptor content, as reported by many authors $(20,21,23)$, but we found that, performing a multivariate analysis, the negative association between progesterone receptor and EGF receptor is not independent and merely shows the strong association between progesterone receptor and estrogen receptor.

The inability to detect specific EGF binding in a large proportion of tumours analyzed ( $42 \%$ of the tumours in our study), has been attributed to several factors: the degradation of EGF receptor during homogenization by the action of endogenous proteases, or occupation of the receptor by endogenous EGF or EGF-like substances produced in an autocrine way (24) which impedes the receptor determination in a binding assay. This is consistent with studies performed on human cell lines for the production of tumour growth factors (26), but has recently been ruled out by other authors (26). Another possibility adduced is that since EGF receptor has been found in normal breast cells, its expression may have been lost in some tumours as a consequence of processes of malignant transformation. But this does not seem to be the case, since in our series we found a significant relationship (positive) between histopathological grade and EGF receptor-positive percentage and EGF receptor content, as reported in other studies (27). 
Some immunochemical studies show that in estrogen receptor-negative/EGF receptor-positive tumours the estrogen receptor and EGF receptor expressions are mutually exclusive within individual cells (28), and it has been hypothesized that the expression of estrogen receptor may decrease and EGF receptor may increase in a particular population of cells in the later stages of malignant progression. In our series this subgroup of tumours was predominant among those without inverse correlation between estrogen and EGF receptors. We agree that the estrogen receptor-negative/EGF receptor-positive subgroup of tumours may be transitional between estrogen receptor-positive/EGF receptor-negative and estrogen receptor-negative/EGF receptor-positive tumours, indicating a tendency towards a lack of response to the therapy.

In our study, the relationship between EGF receptor and the different histopathological type of tumour was non-significant. We did not find any relationship be-

\section{References}

1. Cohen S. Isolation of a mouse submaxillary gland protein accelerating incisor eruption and eyelid opening in the newborn animal. J Biol Chem 1962; 237:1555-62.

2. Carpenter G, Cohen S. Epidermal growth factor. Ann Rev Biochem 1979; 48:198-216.

3. Osborne CK, Hamilton B, Titus G, Livingston RB. Epidermal growth factor stimulation of human breast cancer cells in culture. Cancer Res 1980; 40:2362-6.

4. Fitzpatrick SL, LaChance MP, Schultz GS. Characterisation of epidermal growth factor receptor and action on human breast cancer cells in culture. Cancer Res 1984; 44:3442-7.

5. Bargmann CI, Hung MC, Weinberg RA. The neu oncogene encodes an epidermal growth factor receptor related protein. Nature 1986; 319:226-9.

6. Carpenter G. Receptors for epidermal growth factor and other polypeptide mitogens. Ann Rev Biochem 1987; 56:881-914.

7. Roberts AB, Frouk CA, Anzano MA, Sporn MB. Transforming growth factors from neoplastic and non-neoplastic tissues. Fed Proc 1983; 42:2621-5.

8. Klijn JGM, Berns PMJJ, Schmitz PIM, Foekens JA. The clinical significance of epidermal growth factor receptor (EGF-R) in human breast cancer: a review on 5232 patients. Endocrine Rev 1992; 1:13-7.

9. Fox SB, Smith K, Hollyer J, Greenall M, Hastrich D, Harris AL. The epidermal growth factor receptor as a prognostic marker: results of 370 patients and review of 3009 patients. Breast Cancer Res Treat 1994; 29:41-9.

10. Klijn JGM, Look MP, Portengen $\mathrm{H}$, Alexeieva-Figusch J, van Putten WL $\bar{J}$, Foekens JA. The prognostic value of epidermal growth factor receptor (EGF-R) in primary breast cancer: results of a 10 year follow-up study. Breast Cancer Res Treat 1994; 29:73-83.

11. Gasparini G, Pozza F, Harris A. Evaluating the potential usefulness of new prognostic and predictive indicators in nodenegative breast cancer patients. J Natl Cancer Inst 1993; 85:1206-19.

12. Harris AL. The epidermal growth factor receptor as a target for therapy. Cancer Cells 1990; 2:321-3.

13. Koenders PG, Faverly D, Beex LV, Bruggink ED, Kienhuis $\mathrm{CB}$, Benraad TJ. Epidermal growth factor receptors in human tween EGF receptor expression and tumour size, nor between EGF receptor and the invasion of axillary lymph nodes, although some authors (8) reported such relationships.

EGF receptor has been reported as a prognostic marker, especially in studies for early relapse-free survival, but the data are rather controversial. In the future, it may be important as an indicator of response to hormonal therapy and even as a target for therapeutical agents. However, this relevance is largely dependent on the reliability of its determination and different methodological approaches to measuring EGF receptor are not equivalent in terms of prognostic power. We think that the standardized methodology for EGF receptor assays, established by the EORTC group, is an easy and reproducible alternative which will expand EGF receptor determination and permit comparability of EGF receptor data between laboratories, and offers an important advance for the clincial trials involving EGF receptor. breast cancer: a plea for standardisation of assay methodology. Eur J Cancer 1992; 28:693-7.

14. Kienhuis CBM, Heuvel JJTM, Ross HA, Swinkels LMJW, Foekens JA, Benraad TJ. Six methods for direct radioiodination of mouse epidermal growth factor compared: effect of non-equivalence in binding behaviour between labeled and unlabeled ligand. Clin Chem 1991; 37:1749-55.

15. Benraad TJ, Foekens JA. Hydroxylapatite assay to measure epidermal growth factor receptors in human primary breast tumours. Ann Clin Biochem 1990; 27:272-3.

16. Scatchard G. The attraction of proteins for small molecules and ions. Ann NY Acad Sci 1949; 51:660-72.

17. Lowry OH, Rosebrough HJ, Farr AL, Randall RJ. Protein measurement with Folin phenol reagent. J Biol Chem 1951; 193:265-75

18. Koenders PG, Beex LVAM, Geurts-Moespot A, Heuvel JJTM, Kienhuis CBM, Benraad TJ. Epidermal growth factor receptornegative tumours are predominantly confined to the subgroup of estradiol receptor-positive human primary breast cancers. Cancer Res 1991; 51:4544-8.

19. Bolla M, Chedin M, Souvihnet C, Marron J, Arnould C, Chambaz E. Estimation of epidermal growth factor receptor in 177 breast cancers: correlation with prognostic factors. Breast Cancer Res Treat 1990; 16:97-102.

20. Pekonen F, Partanen S, Makinen T, Rutanen EM. Receptors for epidermal growth factor and insulin-like growth factor-1 and their relation to steroid receptors in human breast cancer. Cancer Res 1988; 48:1343-7.

21. Skoog L, Macías A, Azavedo E, Lombardero J, Klintenberg C. Receptors for EGF and oestradiol and thymidine kinase activity in different histological subgroups of human mammary carcinomas. Br J Cancer 1986; 54:271-6.

22. Lee CSL, Hall RE, Alexander IE, Koga M, Shine J, Sutherland $R L$. Inverse relationship between estrogen receptor and epidermal growth factor receptor mRNA levels in human breast cancer cell lines. Growth Factors 1990; 3:97-103.

23. Foekens JA, Portengen H, Janssen M, Klijn JGM. Insulin-like growth factor-1 receptors and insulin-like growth factor-1-like activity in human primary breast cancer. Cancer 1989; 63:2139-47. 
24. Salomon DS, Zwiebel JA, Bano M, Losonezy I, Fechnel P, Kidivell WR. Presence of transforming growth factors in human breast cancer cells. Cancer Res 1994; 44:4069-77.

25. Vickers PJ, Dickson RB, Shoemaker R, Cowan KH. A multidrug-resistant MCF-7 human breast cancer cell line which exhibits cross-resistance to antiestrogens and hormone-independent tumor growth in vivo. Mol Endocrinol 1988; 2:886-92.

26. Kienhuis CBM, Koenders PG, Klominska H, Benraad TJ. Endogenous ligands for the epidermal growth factor receptor in human breast tumors do not interfere in an epidermal growth factor receptor radioligand binding assay. Breast Cancer Res Treat 1993; 3:271-5.

27. Bolufer P, Miralles F, Rodriguez A, Vazquez C, Lluch A, Carcia-Conde J, et al. Epidermal growth factor receptor in hu- man breast cancer: correlation with cytosolic and nuclear ER receptors and with biological and histological tumor characteristics. Eur J Cancer 1990; 3:283-90.

28. Sharma AK, Horgan K, Douglas-Jones AG, McCleland RA, Nicholson RI. Double immunocytochemical assay of receptors for oestrogen (ER) and epidermal growth factor (EGFR). Breast Cancer Res Treat 1992; 23:185.

\author{
Orland Diez-Gibert \\ Dr. Klein, 5, 4rt, $2^{\mathrm{a}}$ \\ Cardedeu 08440 \\ Barcelona \\ Spain
}

